\title{
A Theoretical Model for Institutional Change: The Relationship between Institutional Entrepreneurship and Social Capital
}

\author{
Sule Tuzlukaya ${ }^{1} \&$ Erdem Kirkbesoglu ${ }^{2}$ \\ ${ }^{1}$ Faculty of Business Administration, Atilim University, Ankara, Turkey \\ ${ }^{2}$ Faculty of Commercial Sciences, Baskent University, Ankara, Turkey \\ Correspondence: Erdem Kirkbesoglu, Faculty of Commercial Sciences, Baskent University, Ankara, Turkey. \\ E-mail: erdemk@baskent.edu.tr
}

Received: December 4, 2014

Accepted: January 2, 2015

Online Published: February 27, 2015

doi:10.5539/ijbm.v10n3p91

URL: http://dx.doi.org/10.5539/ijbm.v10n3p91

\begin{abstract}
This study demonstrates theoretically at which level the social capital and embedded relationships can be beneficial for institutional entrepreneurs to achieve institutional change. For this purpose, a model is proposed, based on three propositions, to examine the effectiveness of the social capital possessed by institutional actors to attain institutional change. In this way two different fields-mainly institutional theory and social network theory-are combined in order to further explain institutional change.
\end{abstract}

Keywords: institutional entrepreneurship, institutional change, social capital

\section{Introduction}

Within the last twenty years, research related to the institutional theory has shifted from isomorphism towards some new subjects. In particular, discussions have increased in number related to institutional change, institutional entrepreneurship and also those related to the question of whether the exogenous or endogenous factors have an impact on the institutional change (Leca, Battilana \& Boxenbaum, 2008; Maguire, Hardy \& Lawrence, 2004; Dorado, 2005; Fligstein, 2001). From these discussions, the view that supports the effect of endogenous factors on the institutional change points out to the actors as institutional entrepreneurs. In particular, since the word 'institutional' refers to inertia and stability, and that 'entrepreneurship' refers to change and newness, this makes institutional entrepreneurship very important from the perspective of recognizing new opportunity fields and triggering institutional change (Strang \& Sine, 2002; Leca, Battilana \& Boxenbaum, 2008; David \& Bitektine, 2008).

According to Lawrence and Suddaby (2006), institutional entrepreneurs not only play very crucial roles in expanding the awareness concerning new opportunity fields and niches, they also create change in the existing systems and take over disseminating new ideas. The above- mentioned actors, referred to as institutional entrepreneurs' in the literature, create institutions by mobilizing the resources and/or transforming the existing ones (Garud, Hardy, \& Maguire, 2007; Leca, Battilana, \& Boxenbaum, 2008). In order to be successful, these actors often choose to build strategic partnerships or cooperation (Leblebici et al., 1991).

Recently, growing interest in the concept of institutional entrepreneurship may also relate to the efforts to provide a more vivid description in structure-agency discussions. Besides this, other efforts focus on searching for a satisfactory answer as to who the initiators of the institutional change are. Researchers in this process attempt to clarify the questions as to why and how cultural factors or norms embedded in organizational life have changed by the entrepreneur actors.

Studies on the types of institutional entrepreneurship and their role in the institutional change are abundant in the literature. However, those investigating the resources employed by entrepreneurs to create change are relatively few. It is obvious that actors, being a member of certain networks, tend to reduce uncertainty and, in the meantime, to use new and valuable information for their own benefits. In other words, to achieve institutional change, many opportunities can be created by membership to social and organizational networks which may provide benefits and support in achieving organizational objectives.

The aim of this study is to demonstrate theoretically what degree of embeddedness and social capital is necessary to achieve institutional change. In this context, by benefiting from the social network theory, the social 
embeddedness approach and institutional theory, propositions are developed to observe the effectiveness of the social capital of the actors for achieving institutional change.

The paper is organized as follows: in the upcoming section, the authors explain who the institutional entrepreneurs are and the triggering factors related to the institutional change. Later, propositions are formed as to institutional entrepreneurs and social embeddedness. In the third section, categories are created regarding the propositions set forth. Finally, the conclusion wraps up the findings.

\section{The Focus of Change for Institutional Entrepreneurs}

The two approaches of institutional theory-the old and the new institutional theories-consider institutional change in two different lights; old institutional theory assumes the institutional environment will not change without the impact of exogenous factors; whereas the new institutional theory draws attention to the roles played by the embedded actors (Colomy, 1998). For example, Barba-Sanchez and Molina (2014) highlight the importance of indigenous communication as entrepreneurs. The major difference between the old and the new institutional theory research topics is somehow related to the role they assign to institutional entrepreneurs through the realization of institutional change. Recent studies focus on the concept of such change in institutional theory, and that institutions are created by actors instead of examining the deterministic effects of institutions on individuals and organizations. These studies, to test the actors' actions, have been associated with the concept of institutional entrepreneurship (Heugens \& Lander, 2009). The main emphasis of these studies dealing with institutional entrepreneurs is 'change'. Since institutionalization "is an incomplete process" (DiMaggio, 1988: 12), the continuity of this process always makes institutional entrepreneurs the essential factors. More precisely, institutional change may occur not only by external pressures, such as state or professional organizations, but also by the strategic actions of the actors existing in the organization. In this way, by mobilizing the resources for their interests, these actors are able to create change and to use new areas of opportunity (Garud, Hardy \& Maguire, 2007; Battilana, 2006; Leca, Battilana \& Boxenbaum, 2008; Lawrence \& Suddaby, 2006).

In the studies related to the change process, fundamental questions are raised as to who the actors are, how the power relations of the actors are formed, how change and transformation in the organizational field happens as a result of these power relations and how the actors mobilize their strategic resources in this process. Interorganizational isomorphism is the result of a number of interactions between the actors existing in the organization. Hoffman (1999) emphasizes in his study that there is a logic present in the institutional fields, and that this logic is the pattern formed and affected by the actors located within that field. Accordingly, to form such a field, the actors' discourses and actions for legitimizing the direction of their actions are very important as well as their efforts to affect and persuade the other actors they interact with. Therefore, it is a necessary to take into account the power possessed by the actors alongside their role in the institutional change process.

Changes within the institutional field include complex processes. Actors and different power relations are all involved in the change process. Given that institutional changes are frequent and not easy to accomplish, it is necessary to draw attention to the importance of those who realize the need for such change. Furthermore, the necessary capacity and skills of these actors to carry out the change and being in the right position in the organizational field are also quite essential and need attention.

The concept of institutional entrepreneurship, first introduced by DiMaggio (1988), focuses on the lack of explanation for change without considering the political processes, interests and conflicting issues within organizations. Pacheco et al. (2010) describe institutional entrepreneurs both as innovative and as agents of change. In such circumstances, actors are interested in the existing institutional practices and take action in order to create new institutions and to transform the existing fields. In a way, this is associated with their strategic position. For example, by mobilizing organizational and cultural opportunities, in order to develop social legitimacy and interests, such elite social actors as businessmen, professionals, academics and intellectuals draw attention to the need for organizational change and are known for their frequent efforts to spread specific management-related knowledge and expertise (Ozen, 2002).

Since DiMaggio's (1988) study, research related to institutional entrepreneurship has developed quite well. However, these studies, rather than mainly focusing on the structure or actor(s), often refer only to the interaction between the structure and agency. For example, Leca and Naccache (2006) emphasize on the actions of the actors embedded in the structure, stating that, in this way, actors may change the existing institutions or add newness by creating specific strategies. They indicate that the main element shaping the actors' actions are structural factors, which are depended upon the context and, obviously, there is a relationship between action and context (Ozen, 2002). Here, context is not only an external environmental condition that triggers change, it is also present in the subjective interpretations of the actors in the process of change, in which structures and 
processes are intertwined (Pettigrew et al., 2001). Briefly, that the institutions are created by actors does not mean they do not affect the actors. Therefore, almost all of these studies suggest that the interaction between actors and structures must be understood in order to understand the structure-action contrast.

Institutional entrepreneurs, despite the pressure of stability and uniformity in the field that they are embedded within, still perform their actions and mobilize resources in order to create institutions or transform the existing ones (Garud, Jain, \& Kumaraswamy, 2002). For example Ozen (2002) reveals that in the Turkish business system the discourse undertaken by the institutional entrepreneurs in charge of large capital groups shape the diffusion process of total quality management. In his study, it is emphasized that actors try to legitimize total quality management and convert it into a form different from its original version (Ozen, 2002).

According to Perkmann and Spicer (2007), institutional entrepreneurs are the actors able to think forward and with imagination. As the actors of change, they not only resist institutional pressures, but also respond to them and, in many cases, carry out further change (Van de Ven \& Hargrave, 2004). Also as the entrepreneurs, they take risks (George, 2011). At the same time, institutional entrepreneurs, by creating new meaning and value sets, also tend to keep the different institutional practices together in one place (Garud, Hardy \& Maguire, 2007). Child, Li and Tsai (2007) stated that actors may be of different roles in the formation of a field; some of them play a role in its identification and establishment, whereas others may be in the position of adaptors or followers. Therefore, those who bring newness into the field and introduce it are called 'institutional entrepreneurs' (Child et al., 2007).

The factors that encourage institutional entrepreneurs towards change are usually dependent on two elements: field-level factors and the position of actors in the field (Leca, Battilana \& Boxenbaum, 2008). Field-level factors are defined as the precipitating jolts, crises, unexpected events and changes that occur in the organizational field. For example, technological change, changes taking place in the competitive conditions, changes in the law, and scarcity of resources. Such changes or uncertainties may cause the formation of new ideas and values for the actors. Although uncertainty appears as a disadvantage for organizations under normal conditions, if institutional entrepreneurs notice the gaps in the field based on uncertainty and instability, they can use it to their benefit.

When evaluated in terms of the specific characteristics of actors and their position in the field, environmental opportunities, innovations, gaps and interactions between the actors can also trigger institutional entrepreneurship (Seo \& Creed, 2002; Perkmann \& Spicer, 2007). However, the actors may not feel the need to initiate institutional change since they are already embedded as agents within the existing institutional logic. Similarly, they may not need to change the old institutional logic when they only focus on the new logic (Greenwood \& Hinings, 1996). According to Dorado (2005), the awareness of actors related to the alternatives in different contexts, gaps or innovations and their ability to put this awareness into action are all associated with their social skills, motivation and creativity.

Another issue worth considering is that the actions of institutional entrepreneurs towards change may not necessarily be appreciated all the time, even encountering resistance on different occasions. Therefore, in oder to be successful in their actions, institutional entrepreneurs need to gain legitimacy during change and entrepreneurial processes.

\section{Institutional Entrepreneurs and Social Embeddedness}

Regularly, organizations have mutual social and economic relations with other organizations, thereby creating a social network (Gulati et al., 2002). Organizational network refers to relationships with other organizations within the same network; in particular the need to access strategic information, become global and professional, and be able to outsource increases the importance of such organizational networks (Porter and Powell, 2006). Therefore, one could argue that the organizations born in a rich network of relationships may have more chances to gain a competitive advantage. At this point, the main problem is how these organizations create their network relationships.

According to the discussions on embeddedness, an organization's ability to obtain gains through network relationships is based on its strategic actors. The concept of embeddedness suggests that the complex social networks of small or big actors who have a role in the economic life and who possess different features may affect interorganizational issues such as competition, price, supply and demand. Also, actors positioned at the top management level of the organization can transfer a series of strategic knowledge and practices they observe through their networks as a model for their own organizations. Various investment decisions can be made through these networks, partnerships, strategic alliances or structural changes. In other words, organizational actions are often performed by learning through social networks (Galaskiewicz \& Wasserman, 1989; Granovetter, 
1985).

If organizational actions are fed through the existing social relationships, the quality and quantity of such relationships may bring about positive effects on performance. Behind organizational success, it is obvious that there lies the strategic actions of the managers. However, such success can not only be explained by years of experience gained within an organization, but also by such individuals' previous achievements obtained through social relations (Gargiulo \& Benassi, 2000). Many studies emphasize that in modern economies, the actors with embedded relationships have an advantage over those that are isolated (Granovetter, 1985; Uzzi, 1996; Podolny, 2005). Actors' actual, potential, tangible and intangible resources gained through social relations constitute their social capital (Bueno et al., 2004; Gargiulo \& Benassi, 2000; Nahapiet \& Ghoshal, 1998; Sargut et al., 2007). Thus, social capital refers to tangible and intangible gains achieved through institutionalized and permanent embedded network relationships (Sargut, 2006). Actors often manage the social capital they have to achieve certain organizational objectives. For example, they may develop their social capitals through a variety of club or association memberships, participation in social activities or charities, or by undertaking corporate social responsibility projects. The information obtained through these networks can provide opportunities for valuable organizational investment decisions, identifying potential areas of opportunity, winning different tenders, providing cheaper resources, and forming further partnerships.

The actors' positions in social networks affect their perceptions of the field as well as their tendency towards institutional entrepreneurship (Nee \& Ingram, 1998; Dorado, 2005). Institutional entrepreneurs who change pre-dominant institutional rules and practices and replace them with new ones do so with the advantage of having sufficient resources and/or social capital (Leca, Battilana, \& Boxenbaum, 2008; Battilana, 2006). The embedded relationships gained through organizational networks they belong to support their actions in terms of the discourse as well as the ideas necessary to realize institutional change. Perkmann and Spicer (2007) stated that the first stage of institutional change begins with the actions of institutional entrepreneurs to form a coalition, negotiate, convince other actors, and mobilize the resources in this direction. Therefore, the mature embedded relationships within the network are an important factor in promoting the idea of institutional change. In this way, the first proposition is set forth as follows:

Proposition 1: In organizational networks with a high level of embeddedness, the probability of institutional change is also higher compared to those with a low embeddedness level.

The structural features of the field consist of institutions and organizational networks. This both limits the actors and also contributes to the legitimacy of their ideas. The position of the actors in the organizational network affects their reputation, the entrance and exit of the new actors and the spreading of ideas (Beckert, 2010). Closed social networks are those in which the actors are intensely connected with one another and are based on trust. Such tight relationships based on trust develop a reputation among actors, who often prefer not to establish any other connections outside that network. Although, such over-confidence in close networks can at times block the view of opportunities outside the circle (Brass et al., 2004). Kraatz (1998) stated that strong relationships with other actors can reduce uncertainty by increasing communication and information sharing; however, this makes change more difficult. Also, maintaining such interactions in a repetitive cycle over time leads to the repetition of the same actions within the network (Zaheer \& Soda, 2009). For this reason, reduced diversity and increased homogeneity in closed networks can impact the possibility of identifying other actors within a network. To sum up, a relatively closed network can be regarded as an obstacle to the realization of institutional change. Our second proposition is formed on this basis as:

Proposition 2: In relatively closed networks, the probability of realizing institutional change is low compared to open organizational networks.

As mentioned before, it is important to access rare and critical resources by institutional entrepreneurs necessary to gain success. The weak ties approach in the social network theory, suggests that the resources are usually transferred from established market relations instead of friendly and reliable ones (Uzzi, 1996; Granovetter, 1985). Actors who exchange information and resources through weak ties have relatively more important positions in the field (Ahuja, 2000; Burt 2004; Burt, 2005 Burt, 2010). This is because weak ties allow new and useful information transfer from different clusters. Even established with not very strong ties, useful information and new applications are achieved through these market relations. Therefore, having weak ties with different clusters supports the movement of new knowledge to the organizational networks. Gaining the advantage of brokerage between clusters that are not connected, actors increase their power in terms of legitimacy, credibility and strategic importance within the network (Brass et al., 2004). The ideas obtained through brokerage mean movement of an ordinary idea within one group to another group, which finds that idea new and valuable for 
itself (Burt, 2005). Fligstein (1997) stressed that, by using their social capital, institutional entrepreneurs can break the link between some groups, form new ones and establish partnerships. Also, Greve and Salaff (2003) emphasize that entrepreneurs require information, capital and skills in order to take action. They may already possess a portion of resources, the rest of which can be obtained through relationships. Thus, actors with extensive social capital and interaction with different sets of actors can also be the initiators of any change in the network. The positions of these actors in social networks also influence their tendency towards institutional entrepreneurship and perceptions about the field (Nee \& Ingram, 1998; Dorado, 2005). The appearance and mobilization of institutional change is related with experience and observation coming from such sparse market relations obtained in different times instead of repeated networks. Such relationships allow institutional entrepreneurs to gain a different vision and a brand new sense of perception in terms of organizational life. Thus, proposition three appears as below:

Proposition 3: The probability of the realization of institutional change is higher if the density of sparse market relationships established with different networks is high.

In other words, the possibility of institutional change is affected by whether the relationships are in-network or out-network, and also whether they are based on either embedded networks or sparse networks. Both dimensions affecting organizational change are part of the social capital of the actors. According to Sargut (2006), such capital is determined by two elements: the power of connections and networks. Figure 1 represents our three testable propositions. Accordingly, for the emergence of the idea of change, the market relationships outside the group are essential. However, this must be supported by built in-network relationships within the group in order to make such relationships accepted. Therefore, actors with embedded relations within the group and market relations outside the group (Box 1+4) increase the probability of becoming entrepreneurship. In contrast, having sparse relationships (Box 3) can cause disapproval of their idea of change. In this case, the connections established outside will not matter.

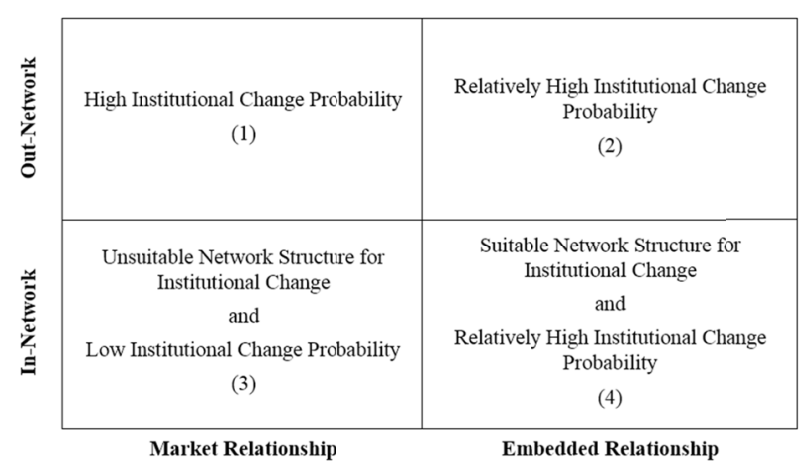

Figure 1. The possibility of institutional change and social capital

\section{Summary and Tentative Conclusions}

Since DiMaggio's study of institutional entrepreneurship (1988), the main reason for the increase in the number of studies so far on this subject has been the resolution of the ongoing debate between the structure-action. Institutional entrepreneurs play an important role in the creation of new organizational niche areas, replacing existing ones, or approval of new ones. Despite the fact that there are many researches in the literature related to institutional entrepreneurs' role in institutional changes, in particular the diffusion and adopting of institutional practices, the question as to through which resources this change is to become successful has remained unanswered. The existing literature, despite mentioning the importance of institutional entrepreneurs having sufficient resources in the change process, does not explain what kind of relationship networks those resources can be obtained from.

The aim of this study has been to demonstrate theoretically what degree of embedded relations and social capital can be beneficial to institutional entrepreneurs in terms of realizing institutional change. The social capital literature offers clues for the important role of social network relations for institutional entrepreneurs' success in achieving institutional change. This feature is based on the changing nature of relations according to actors inside and outside of the network bringing about institutional change. The ideas proposed in this study show that those actors with embedded relationships in groups and market relations on the outside groups enjoy higher 
chances of realizing institutional change. However, those with sparse networks may not be able to gain sufficient support for change. In their case, the outside connections also become insignificant.

In bringing the social network approach to institutional entrepreneurship, we aim to draw attention to the embedded relations and social capital of institutional entrepreneurs in terms of realizing of institutional change. However, the limitations of the study should not left disregarded; specifically, the topics related to network destruction and change should also be considered since either the actors as institutional entrepreneurs or their power and interest may change. Naturally, in general the propositions/results may differ when it comes to different organizational settings and/or different industries. Furthermore the effect of culture may also be considered in future studies. Obviously, the three theoretical propositions put forth here can be further tested in terms of validity.

\section{Acknowledgments}

The authors would like to express their appreciation to Mr. Payem Danesh from the Academic Writing and Adviser Center at Attlım University for helping to redraft the present manuscript.

\section{References}

Ahuja, G. (2000). The duality of collaboration: Inducements and opportunities in the formation of inter firm linkages. Strategic Management Journal, 213, 317-343. http://dx.doi.org/10.1002/(SICI)1097-0266(200003)21:3<317::AID-SMJ90>3.0.CO;2-B

Barba-Sanchez, V., \& Molina, E. (2014). Entrepreneurship as a Survival-Seeking Strategy for Indigenous Communities: The Case of Indigenous Ecotourism SMEs in Mexico. In Todorov, K. \& Smallbone, D. (Eds.), Handbook of Research on Strategic Management in Small and Medium Enterprises, IGI Global (pp. 398-420). http://dx.doi.org/10.4018/978-1-4666-5962-9.ch019

Battilana, J. (2006). Agency and Institutions: The enabling role of individuals' social position. Organization, 135, 653-676. http://dx.doi.org/10.1177/1350508406067008

Beckert, J. (2010). How do fields change? The interrelations of institutions, networks and cognition in the dynamics of markets. Organization Studies, 31(5), 605-627. http://dx.doi.org/10.1177/0170840610372184

Brass, D. L., Galaskiewicz, J., Greve, H., \& Tsai, W. (2004). Taking stock of networks and organizations: A multilevel perspective. Academy of Management Journal, 47(6), 795-817. http://dx.doi.org/10.2307/20159624

Bueno, E., Salmodor, P. M., \& Rodriguez, O. (2004). The role of social capital in today's Economy. Journal of Intellectual Capital, 54, 556-574. http://dx.doi.org/10.1108/14691930410567013

Burt, R. S. (2004). Structural holes and good ideas. American Journal of Sociology, 110, 349-399. http://dx.doi.org/10.1086/421787

Burt, R. S. (2005). Brokerage and Closure: An Introduction to Social Capital. Oxford: UK.

Burt, R. S. (2010). Neigbour Networks: Competitive Advantage Local and Personal. Oxford University Press.

Child, J., Lu, Y., \& Tsai, T. (2007). Institutional Entrepreneurship in Building and Environmental Protection System for the People's Republic of China. Organization Studies, 28, 1013-1034. http://dx.doi.org/10.1177/0170840607078112

Colomy, P. (1998). Neofunctionalism and neoinstitutionalism: Human agency and interest in İnstitutional change. Sociological Forum, 132, 265-300. http://dx.doi.org/10.1023/A:1022193816858

David, R. J., \& Bitektine, A. B. (2008). The Deinstitutionalization of Institutional Theory? Exploring Divergent Agendas in Institutional Research. In Greenwood, R., Oliver, C., Sahlin, K., \& Suddaby, R. (Eds.), The Sage Handbook of Organizational Institutionalism. Sage Publication.

DiMaggio, P. J. (1988). Interest and agency in institutional theory. In L. G. Zucker (Ed.), Institutional patterns and organizations: Culture and Environment. Cambridge, Massachusetts. Ballinger.

Dorado, S. (2005). Institutional entrepreneurship, partaking and convening. Organization Studies, 26(3), 385-414. http://dx.doi.org/10.1177/0170840605050873

Fligstein, N. (1997). Social skill and institutional theory. American Behavioral Scientist, 40, 397-405. http://dx.doi.org/10.1177/0002764297040004003

Fligstein, N. (2001). Social skill and the theory of fields. Retrieved from http://www.irle.berkeley.edu/culture/papers/Fligstein01_01.pdf 
Galaskiewicz, J., \& Wasserman, S. (1989). Mimetic processes within an inter-organizational field: An empirical test. Administrative Science Quarterly, 34, 454-479. http://dx.doi.org/10.2307/2393153

Gargiulo, M., \& Benassi, M. (2000). Traped in your own net? Network cohesion, structural holes, and the adaptation of social capital. Organization Science, 11(2), 183-196. http://dx.doi.org/10.1287/orsc.11.2.183.12514

Garud, R., Hardy, C., \& Maguire, S. (2007). Institutional Entrepreneurship as Embedded Agency: An Introduction to the Special Issue. Organization Studies, 28, 957-969. http://dx.doi.org/10.1177/0170840607078958

Garud, R., Jain, S., \& Kumaraswamy, A. (2002). Institutional Entrepreneurship in the sponsorship of common technological standards: The case of Sun Microsystems and Java. Academy of Management Journal, 45(1), 196-214. http://dx.doi.org/10.2307/3069292

George, B. A. (2011). Entrepreneurial Orientation: A Theoretical and Empirical Examination of the Consequences of Differing Construct Representations. Journal of Management Studies, 486, 1291-1313. http://dx.doi.org/10.1111/j.1467-6486.2010.01004.x

Granovetter, M. (1985). Economic action and social structure: The problem of embeddedness. American Journal of Sociology, 91, 481-510. http://dx.doi.org/10.1086/228311

Greenwood, R., \& Hinings, C. R. (1996). Understanding radical organizational change: Bringing together the old and new institutionalism. Academy of Management Review, 214, 1022-1054.

Greve, A., \& Salaff, J. W. (2003). Social netwoks and entrepreneurhip. Entrepreneurship: Theory and Practice, 28(1), 1-22. http://dx.doi.org/10.1111/1540-8520.00029

Gulati, R., Dialdin, D., \& Wang, L. (2002). Organizational Networks. In Baum, J. (Ed.), The Blackwell Companion to Organizations. Oxford: Blackwell.

Heugens, H. P., \& Lander, M. W. (2009). Structure Agency and other quarrels: A meta analysis of institutional theories of organization. Academy of Management Journal, 52(1), 61-85. http://dx.doi.org/10.5465/AMJ.2009.36461835

Hoffman, A. (1999). Institutional evolution and change: Environmentalism and the US chemical Industry. Academy of Management Journal, 42(4), 351-371. http://dx.doi.org/10.2307/257008

Kraatz, M. S. (1998). Learning by Association? Interorganizational Networks and Adaptation to Environmental Change. Academy of Management Journal, 41(6), 621-643. http://dx.doi.org/10.2307/256961

Lawrence, T. B., \& Suddaby, R. (2006). Insitutions and institutional work. In Clegg, S. R. C., Hardy, T., Lawrence, B., \& Nord, W. R. (Eds.), Handbook of organization studies (pp. 215-254). Sage.

Leblebici, H., Salancik, G. R., Copay, A., \& King, T. (1991). Institutional change and the transformation of interorganizational fields: An organizational history of the U.S. radio broadcasting industry. Administrative Science Quarterly, 36, 333-363. http://dx.doi.org/10.2307/2393200

Leca, B., \& Naccache, P. (2006). A critical realist approach to institutional entrepreneurship. Organization, 13(5), 627-651. http://dx.doi.org/10.1177/1350508406067007

Leca, B., Battilana, J., \& Boxenbaum, E. (2008). Agency and Institutions: A Review of Institutional Entrepreneurship. Retrieved from http://egateg.usaidallnet.gov/sites/default/files/Review\%20of\%20Institutional\%20Entrepreneurship.

Maguire, S., Hardy, C., \& Lawrence, T. (2004). Institutional Entrepreneurship in Emerging Fields: HIV/AIDS treatment advocacy in Canada. Academy of Management Journal, 75(5), 1-23.

Nahapiet, J., \& Ghoshal, S. (1998). Social capital, Intellectual capital and the organizational advantage. Academy of Management Review, 23(2), 243-266.

Nee, V., \& Ingram, P. (1998). Embeddedness and beyond: Institutions, exchange and social structure. In Mary B., \&Victor, N. (Ed.), The new institutionalism in sociology. New York: Russell Sage Foundation.

Özen, Ş. (2002). Bağlam, Aktör, Söylem ve Kurumsal Değişim: Türkiye’de Toplam Kalite Yönetiminin Yayılım Süreci. Yönetim Araştırmaları Dergisi, 12, 47-90.

Pacheco, D. F., York, J. G., Dean, J., \& Sarasvathy, S. D. (2010). The coevolution of Institutional 
Entrepreneurship: A Tale of Two Theories. Journal of Management, 36(4), 974-1010. http://dx.doi.org/10.1177/0149206309360280

Perkmann, M., \& Spicer, A. (2007). Healing the scars of history: projects, skills and field strategies in $\begin{array}{lllll}\text { institutional entrepreneurship. } & \text { Organization } & \text { Studies, } & 28, & 1101-1122 .\end{array}$ http://dx.doi.org/10.1177/0170840607078116

Pettigrew, A., Woodman, R., \& Cameron, K. (2001). Studying Organizational Change and Development: Challenges for Future Research. Academy of Management Journal, 44(4) 697-713. http://dx.doi.org/10.2307/3069411

Podolny, J. M. (2005). Status and Signals. A Sociological study of market competition. Princeton University Press. UK

Porter, K. A., \& Powell, W. W. (2006). Networks and organizations. In S. Clegg, C. Hardy, T. B. Lawrence, \& Ve W. Nord (Eds.), The Sage Handbook of Organization Studies (2nd ed., pp.776-799). London: Sage.

Sargut, A. S., Varoğlu, K. A., Ozen, S., Oguz, F., Sozen, C. H., Yeloglu, O., \& Sagsan, M. (2007). Ulusal İş̧ Sistemi ve Örgüt Ağları: Devlete Bağımlılık ve Merkez-Çevre İkiliğinin Örgütler Arası İlişkilere Etkisi, TÜBITAK Projesi.

Sargut, A. S. (2006). Sosyal sermaye: Yapının sunduğu bir olanak mı, yoksa bireyin amaçlı eylemi mi? Akdeniz I.I.B.F Dergisi, 12, 1-13.

Seo, M., \& Creed, W. E. D. (2002). Institutional contradictions, praxis and institutional change: A dialectical perspective. Academy of Management Review, 27(2), 222-247.

Strang, D., \& Sine, W. D. (2002). Interorganizational institutions. Joel A. C. Baum Der the Blackwell Companion to Organizations (pp. 497-519). Oxford: Blackwell.

Uzzi, B. (1996). The sources and consequences of embeddedness for the economic performance of organizations: The network effect. American Sociological Review, 61(4), 674-698. http://dx.doi.org/10.2307/2096399

Van de Ven, A. H., \& Hargrave, T. J. (2004). Social, Technical, and Institutional Change: A Literature Review and Synthesis. In Poole, M. S., \& Van de Ven, A. H. (Eds.), Handbook of Organizational Change (pp. 259-303). New York: Oxford University Press.

Zaheer, A., \& Soda, G. (2009). Network Evolution: The Origins of Structural holes. Administrative Science Quarterly, 51, 1-31. http://dx.doi.org/10.2189/asqu.2009.54.1.1

\section{Copyrights}

Copyright for this article is retained by the author(s), with first publication rights granted to the journal.

This is an open-access article distributed under the terms and conditions of the Creative Commons Attribution license (http://creativecommons.org/licenses/by/3.0/). 